\title{
Nexus between Indigenous Ecological Knowledge and Ecosystem Services: A Socio-Ecological Analysis for Sustainable Ecosystem Management
}

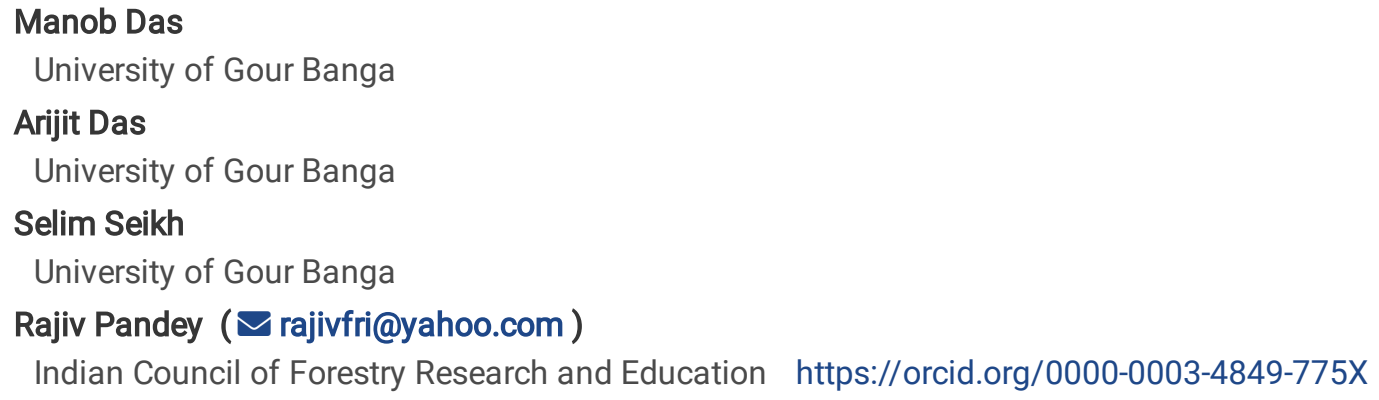

\section{Research Article}

Keywords: Cultural Services, Customs, Ritual, Socio-ecological System, Taboos, Totems

Posted Date: June 7th, 2021

DOI: https://doi.org/10.21203/rs.3.rs-519222/v1

License: @ (1) This work is licensed under a Creative Commons Attribution 4.0 International License. Read Full License

Version of Record: A version of this preprint was published at Environmental Science and Pollution Research on August 5th, 2021. See the published version at https://doi.org/10.1007/s11356-021-15605-8. 


\section{Abstract}

The well-being of the human society cannot be ensured and sustainable unless the flow of Ecosystem Services (ESs) would be matching with their consistent demand. The consistent flow of ESs required sustainable management of ecological resources of the ecosystem. The management of ecosystem can be ensured with variety of approaches. Integration of indigenous ecological knowledge (IEK) in management prescription with the view that IEK based extraction of ESs ensures removal of resources from the ecosystem within the limit thereby ensuring the sustainability of ecosystem. Present study is an evaluation to understand the nexus between ESs and IEK for sustainable environmental management. The focus of the study was a tribal dominated socio-ecological patch of Barind Region of Malda district, Eastern India. The assessment of ESs and IEK was based on the data collected from the randomly selected tribal households following the pre-tested questionnaire containing questions on ESs as per millennium ecosystem assessment. The data were analyzed following social preference approach, and statistical tests (Krushkal-Wallis and Mann-Whitney). General linear model (GLM) has also been used to examine the impact of socio-demographic attributes on the perceived valuation of ESs. The results revealed that the provisioning ESs (such as water, fuel wood, medical plants) was most preferred followed by cultural and regulating ESs by tribal. Differential importance of ESs was observed among tribal and accounted by gender, education as well as age of the tribe. A gap between the actual accessibility and evaluation of ESs by the tribal communities was also apparent. The socio-demographic attributes have an immense impact on the valuation of ecosystem services and also governed based on the IEK. Various types of indigenous ecological belief systems were closely linked with conservation of ecosystem and sustainable supply of ESs. Present study can contribute to understand socio-ecological nexus with the lens of IEK in tribal dominated ecological landscapes for improved ecosystem and environmental management besides ensuring sustainability of flow of ecosystem services.

\section{Highlights}

- A nexus exits between Indigenous Ecological Knowledge (IEK) and Ecosystem Services (ESs).

- Tribal livelihood revolves around ESs particularly provisioning ecosystem services.

- IEK are crucial for the ecological management in tribal landscapes.

- Socio-demographic factors govern to perceive value of ESs.

\section{Introduction}

Indigenous Ecological Knowledge (IEK), an enterprise consisting both the ecological and social systems, is interwoven leading to ensure the sustenance of both the systems. IEK is a sub-set of community specific indigenous knowledge acquired by the indigenous communities through direct contact with the natural environment since generations (Laudari, 2010; Obiora and Emeka, 2015; GómezBaggethun et al., 2010b; 2013) and varies within individual and community based on their native belief systems (Byg and Balslev, 2004). IEK is a set of prescriptions harnessed by indigenous communities on daily basis for their livelihoods while ensuring the sustainability of socio-ecological system (Akwetaireho and Getzner, 2010;Bhatta et al., 2016; Joos-Vandewalle et al., 2018). IEK is fundamentally vital for livelihood and quality of living (Turner et al., 2000) for tribal; conservation of biodiversity (Gadgil et al. 1993; Berkes et al. 2000) conservation of rare species (Colding, 1998); conservation of protected areas (Johannes 1998) and local natural resource management (NRM) for tribal dominated socio-ecological systems.

Global acknowledgements such as millennium assessment recognized that the livelihood and human well-being (HWB) of the indigenous communities is largely dependent on direct and indirect ESs (MEA, 2005). HWB, as an outcome measure, capture and reflect the bundle of ESs for achieving the basic needs and wants of a tribal community for ensuring the quality of life. Therefore, it is necessary to evaluate the importance of ESs and HWB components to sustain the quality of life of tribal community (Smith et al., 2013). Moreover, Intergovernmental Science-Policy Platform on Biodiversity and ESs (IPBES), has recognized the ES approaches as integral part for sustainable development and HWB under the mission 'to strengthen the science-policy interface for biodiversity and ESs for the conservation and sustainable use of biodiversity, long-term human well-being and sustainable development' (IPBES 2016). In spite of high importance of ES for HWB, the emphasis is more towards the economic valuation of tangible services of ES undermining and discounting the cultural services (Winthrop 2014). Surprisingly, with apparent role of IEK for biodiversity conservation, ecosystem dynamics, community resilience, and sustainable resource use (Berkes et al. 2000; Gadgil et al. 1993; RuizMallén \& Corbera, 2013); integration of IEK for ES approaches is lacking across the literature, therefore, poorly accounting social and cultural services of ecosystem (Chan et al., 2012b; Fisher et al., 2009; Lele et al., 2013). The non-inclusion of IEK leads to 
underrepresentation of cultural services in decision-making framework (Chan et al., 2012a; b) and also against the fourth operating principle of IPBES, which highlights the importance of IEK for the conservation and sustainable use of biodiversity and ecosystems (IPBES, 2016).

Well-being of tribal is largely governed by ESs that positively contributes to livelihood (MEA, 2005; Pandey, 2009; Daw et al., 2011). Various researchers has accounted the social and cultural values of agro-ecological systems using IEK as in India (Das et al., 2012; Harisha et al., 2015; Pandey et al., 2017; Tynsong et al., 2020); and in other countries (Halim et al., 2012; Boafo et al., 2016a, 2016b; Christina et al., 2017). IEK and related practices for various direct and indirect uses of wild plant resources and for other purposes such as weather forecasting, medicinal use of wild plants by tribes ensure promotion of cohesion between the ecosystem and human well-being (Harisha et al., 2015). Moreover, tribal through IEK make cultural adjustment to bio-physical surroundings for proper resources management (Tynsong et al., 2020) such as Alder Based Agro-forestry System, a IEK based agricultural practices since time immemorial by indigenous tribes of Nagaland, India (Das et al., 2012), where root nodule of alder trees facilitates soil fertilization and the roots prevents soil erosion in slopes (Rathore et al., 2010; Das et al., 2012). Moreover, indigenous forest management by the local people are based on social justice and equity (Geronimo et al. 2016) and contributes to water availability, livelihood, biodiversity conservation and health care of the people (Halim et al., 2012). Precisely, the practical applications of ES approaches would be more enriched through the inclusion of IEK (Christina et al., 2017).

The ESs approach is primarily motivated by provisioning services and has not well enriched with the cultural and social services of the ecosystem due to the lackluster treatment to the later services (Chan et al. 2012a, 2012b; Boafo et al., 2016a). Moreover, rapid rate of urbanization, industrialization and economic development resulted into extinction of IEK and also degrading the natural environment (Deng et al., 2015; Deng and Gibson, 2018) that causes large scale degradation of ESs (Schäfer et al., 2012; Zeng et al., 2016). The non-inclusion of cultural services in ES approach (Boafo et al., 2016a) and non-accounting of the disturbances leading to flow of ESs (Malik et al., 2016) would have implications for loss of IEK and cohesion between the ecosystem and human well-being along with degradation of socio-ecological systems. Therefore, a study was conducted to assess the IEK role and contribution for tribal communities, focusing to tribal villages adjacent to the forest in Briand region, Malda districts, India. The objective of the study was assessment of ecosystem services for tribal welfare and role of IEK for management of ecological resources and HWB for suggesting the integration of IEK in ES approach, keeping in view the integral nature of tribal livelihood with forests. Exclusively, the present evaluation has a central goal of ecosystem management with regional planning by accounting and integrating IEK into ES approach through emphasizing the relationship among ESs and IEK for ecosystem management.

\section{Materials And Methods}

\subsection{About study landscapes}

Malda district, West Bengal, India is characterized by low lying alluvial pains with south slope. North-eastern part of the district contains few elevated tracts which are intersected by deep water channels. On the basis of topography, Malda district is divided into three physiographic divisions namely- Barind, Tal and Diara. Barind region spreads in $1348.3 \mathrm{sq} . \mathrm{Km}$. (37.63\%) area of the district

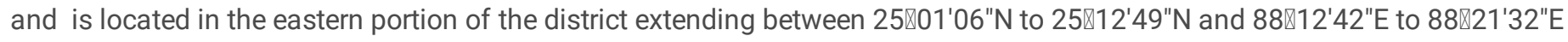
(Figure 1). The region is characterized by ancient alluvial humps and old riverine flood plains. Total Schedule Tribe (ST) population of the area is 182411 consisting 58 percent of the total STs of the district. The Schedule Tribes belong to various racial groups such as Santal (dominated over the region), Hansda, and Oraon tribe. Two tribal dominated villages namely Karanja (Habibpur CD block) and Salbona Village (Gazole CD block) with ethnic origin of Santal and Oraw were selected for study. The villagers were dependent on natural resources for their subsistence livelihood and located around forest area (REFF) (Table 1 and 2). Both the villages are characterized by subtropical monsoon climate with an average annual temperature of $30 \otimes C$ and mean annual rainfall is $1250 \mathrm{~mm}$ (REFF). The primary profession of villagers was agricultural activities. Majority of the people of the villages were unable to avail basic amenities as well as materials for life such as pure drinking water (particularly in Karanja village) access to education and health facilities. Both the villages are located away from nearest central place ( $3 \mathrm{~km}$ from Kendupukur, the nearest small town) and $8 \mathrm{~km}$ from Alampur (nearest central place).

\section{Table 1: Geographical settings of study villages}




\begin{tabular}{|c|c|c|c|c|c|}
\hline Block & Village & Location & Elevation (amsl) & $\begin{array}{l}\text { Estimated land area } \\
\text { (in hectare) }\end{array}$ & Population (as per 2011 Census) \\
\hline \multirow[t]{2}{*}{ Habibpur } & Karanja Forest & $\begin{array}{l}\text { Long } \\
88^{\circ} 19^{\prime} 13^{\prime \prime} \mathrm{E}\end{array}$ & $35-50 \mathrm{~m}$ & 48.76 & 880 \\
\hline & & Lat $25^{\circ} 5^{\prime} 51^{\prime \prime} \mathrm{N}$ & & & \\
\hline \multirow[t]{2}{*}{ Gazole } & $\begin{array}{l}\text { Sal-bona } \\
\text { (Forest) }\end{array}$ & $\begin{array}{l}\text { Long } \\
88^{\circ} 12^{\prime} 35^{\prime \prime E}\end{array}$ & & 125.65 & 1994 \\
\hline & & Lat $25^{\circ} 11^{\prime} 17^{\prime \prime} \mathrm{N}$ & & & \\
\hline
\end{tabular}

Source: Census, 2011 (Area and Population)

Table 2: Socio-demographic profile of study villages

\begin{tabular}{|llll|}
\hline Household Characteristic & Category & \multicolumn{2}{l}{ \% of respondents } \\
\cline { 2 - 3 } Gender & Karanja (Forest) & Salbona (Forest) \\
\hline Education & Male & 52 & 36 \\
\cline { 2 - 3 } & Female & 48 & 64 \\
\hline Primary & 24 & 40 \\
\hline Secondary & 4 & 24 \\
\hline Higher Secondary & 0 & 8 \\
\hline Collage & 4 & 0 \\
\hline Illiterate & 68 & 28 \\
\hline Agricultural labour & 68 & 40 \\
\hline Daily Worker & 16 & 28 \\
\hline Cultivators & 0 & 0 \\
\hline Housewife & 16 & 32 \\
\hline Student & 0 & 0 \\
\hline$<20$ & 4 & 4 \\
\hline $21-40$ & 44 & 40 \\
\hline $41-60$ & 40 & 36 \\
\hline$>60$ & 12 & 12 \\
\hline Age (in years) & & & 4 \\
\hline
\end{tabular}

Source: Primary Field survey

\subsection{Methodology}

\subsubsection{Conceptual framework to evaluate the relationship between ESs and IEK}

The methodological framework for evaluation the nexus between ESs and IEK is reported in Fig 2.

\subsubsection{Typology of ESs}

The ES has been classified into four category as provisioning services (food, water); regulating services (flood and disease control); supporting services (natural cycling, oxygen production) and cultural services (spiritual and cultural benefits) (de Groot et al., 2002). 
Sixteen (16) ESs distributed in four categories was identified on the basis of ecosystem functions; ecological process and the services in the study area.

\subsubsection{Typology of IEK}

The typology of IEK was categorized on the basis of household survey through questionnaire; direct field observation and interview with the informants. The respondents explained the function of the IEK applied at households as well as the community level. IEK in the region is governed through their indigenous socio-cultural belief systems for ascertaining the benefits/services from the nearby ecological units, as elaborated by the locals. On the basis of the survey, the IEKs were categorized into four major domains namely (a) local totems and taboos (b) customs and rituals (c) rules and regulations and (d) protected areas (indigenous) or sacred areas, respectively. A questionnaire containing the detail identification of IEK along with their linkages with Es was developed and verified by pilot survey. The list of IEK was developed based on pre-field visit and through a focus group discussion with aged people.

\subsubsection{Application of SPA for ESs and IEK assessment}

Qualitative and quantitative research methods were used to assess social value of ESs (Kelemen et al., 2014). The information regarding ESs assessment was collected through rating and ranking of ESs (Santos-Martínet al., 2016). Social Preference Approach (SPA) was applied to assess the value of ESs and linkage of IEK with ESs as well as interpret social value of ESs considering perception, individual knowledge and associated value (Ciftcioglu, 2017; Castro et al., 2011; Campbell, 2018).

\subsubsection{Data collection tools and sample size determination}

Data was collected from the two tribal villages during February and March 2019 through questionnaire containing perception about the ESs, delivered by the local ecosystems and about IEK of the tribal communities. The questionnaire was sub-divided into four sections as: (a) general information of the respondents (such as age, gender, educational level, income, profession) (b) identification of major ecosystems and ESs provided by the local ecosystems (c) major drivers of ESs change and (d) identification of IEK and its linkages with ESs, respectively. The field survey was conducted by researchers along with one local villager. The respondents were asked to provide relative value of ESs and IEK based on five point Likert scale,. The respondents of the villages were informed about basic objectives of the study before the start of field survey for obtaining their consent.

A sample of 75 households was selected at $10 \%$ confidence level from the 172 households of the two villages (Asmamaw et al., 2011); and divided proportionally in two villages Karanja (28) and Salbana (32).

$$
n=\frac{Z_{2} \times N \times(1-p)}{e_{2} \times(N-1)+x 2 \times p \times(1-p)}
$$

$\mathrm{n}=$ Sample size; $\mathrm{z}^{2}=$ table value of Chi-square at 1 degree of freedom of the desired confidence interval (3.841); $\mathrm{N}=$ size of the population; $\mathrm{p}=$ expected proportion of population response (0.05), e = desired margin error (expressed in \%).

\subsubsection{Evaluation of the perceived data}

The importance of the ESs was evaluated on five point Likart Scale based on the perception of the households where 5 assigned as very high importance; 4 is assigned as high importance; 3 is assigned as Medium importance; 2 is assigned as low importance; 1 is assigned as very low importance and 0 is assigned as no importance respectively. Responses of no importance provided by households were not recorded (Calvet-Mir et al., 2012; Langemeyer et al., 2016).

\subsubsection{Statistical analysis}

Non-parametric Kruskal-Wallis and Mann-Whitney test was applied to assess the difference in perception of ESs. A generalized linear model (GLM) was applied to examine the impact of socio-demographic attributes on the perceived importance of ESs. Gender, age, educational level and occupational status were taken as the independent (or explanatory variables). All these statistical analysis was performed using SPSS software (Version 22) and Social Science Statistics (SSSs) on line software package.

\section{Result}




\subsection{Valuation of ESs perceived by the Tribal Communities}

The data analysis results that tribal households attached highest importance to provisioning ESs (3.76) followed by regulating ESs (3.47), cultural ESs (3.31) and support services (3.24), respectively. Among all the provisioning ecosystem services, highest importance were attached to water for drinking and bathing (4.86) followed by main food (4.71), material for house (4.17); maintenance of soil fertility (4.07), maintenance of air quality (3.83) and water regulation (3.54) amongst regulating services; spiritual value (3.92), local customs and rituals (3.38) and aesthetic value (2.63) for cultural services; habitat for species (4.01) amongst supporting services, respectively (Table 3). The highest importance to the provisioning ESs by tribal communities was due to their requirement and direct benefits for livelihood. Most of the tribal households were having very limited accessibility and availability to the basic services and amenities such as drinking water facility within premises, good housing conditions. The limited accessibility and availability leads to the households on higher dependency on ESs particularly provisioning ecosystem services, tribal reported.

Table 3: Mean importance of individual ESs based on socio-demographic attributes 


\begin{tabular}{|c|c|c|c|c|c|c|c|c|c|c|c|c|}
\hline \multirow[t]{2}{*}{ Category } & \multirow[t]{2}{*}{ ESs } & \multicolumn{2}{|c|}{ Gender } & \multicolumn{3}{|c|}{ Age range } & \multicolumn{4}{|c|}{ Educational level } & \multirow{2}{*}{$\begin{array}{l}\text { Overall } \\
\text { importance } \\
\text { (Average) }\end{array}$} & \multirow[t]{2}{*}{ Ranking } \\
\hline & & M & $F$ & $\begin{array}{l}20- \\
40\end{array}$ & $\begin{array}{l}41- \\
60\end{array}$ & $>60$ & Pri. & Sec. & H.S & Clg. & & \\
\hline \multirow[t]{8}{*}{ Provisioning } & $\begin{array}{l}\text { Main food } \\
\text { (rice, wheat) }\end{array}$ & 4.9 & 5.0 & 4.8 & 4.9 & 4.5 & 4.6 & 4.7 & 4.4 & 4.6 & 4.71 & \multirow[t]{8}{*}{1} \\
\hline & $\begin{array}{l}\text { Medical } \\
\text { plants }\end{array}$ & 3.6 & 4.7 & 3.8 & 3.9 & 4.1 & 4.3 & 3.4 & 2.9 & 2.6 & 3.70 & \\
\hline & $\begin{array}{l}\text { Water } \\
\text { (drinking, } \\
\text { bathing) }\end{array}$ & 5.0 & 5.2 & 4.6 & 5.2 & 4.9 & 4.8 & 4.8 & 4.7 & 4.9 & 4.86 & \\
\hline & $\begin{array}{l}\text { Wild edible } \\
\text { plants }\end{array}$ & 3.6 & 4.4 & 3.4 & 4.6 & 3.5 & 2.4 & 3.5 & 2.9 & 2.5 & 3.42 & \\
\hline & $\begin{array}{l}\text { Fodder for } \\
\text { livestock }\end{array}$ & 3.8 & 3.8 & 2.9 & 3.8 & 3.6 & 2.8 & 4.1 & 3.6 & 2.6 & 3.43 & \\
\hline & $\begin{array}{l}\text { Materials for } \\
\text { house }\end{array}$ & 4.7 & 4.5 & 4.4 & 4.3 & 4.5 & 3.7 & 3.9 & 3.8 & 3.7 & 4.17 & \\
\hline & Fuel wood & 4.6 & 5.0 & 4.4 & 4.5 & 4.8 & 4.5 & 3.7 & 4.4 & 4.1 & 4.44 & \\
\hline & $\begin{array}{l}\text { Average } \\
\text { importance } \\
\text { of PESs }\end{array}$ & 4.30 & 4.54 & 3.94 & 4.2 & 3.96 & 2.96 & 3.69 & 3.59 & 3.14 & 3.76 & \\
\hline \multirow[t]{5}{*}{ Regulating } & $\begin{array}{l}\text { Maintenance } \\
\text { of the clean } \\
\text { and fresh air }\end{array}$ & 4.1 & 4.2 & 3.4 & 3.3 & 3.9 & 3.3 & 4.1 & 4 & 4.2 & 3.83 & \multirow[t]{5}{*}{2} \\
\hline & $\begin{array}{l}\text { Water } \\
\text { regulation } \\
\text { and } \\
\text { purification }\end{array}$ & 3.8 & 3.6 & 3.5 & 3.3 & 3.4 & 3.6 & 3.2 & 3.7 & 3.8 & 3.54 & \\
\hline & $\begin{array}{l}\text { Seed } \\
\text { dispersals }\end{array}$ & 2.9 & 2.8 & 2.2 & 2.4 & 2.3 & 2.1 & 2.2 & 2.5 & 2.8 & 2.47 & \\
\hline & Soil fertility & 4.4 & 4.2 & 4.1 & 4.3 & 4.1 & 3.1 & 3.9 & 4.2 & 4.3 & 4.07 & \\
\hline & $\begin{array}{l}\text { Average } \\
\text { importance } \\
\text { RESs }\end{array}$ & 3.80 & 3.70 & 3.3 & 3.32 & 3.42 & 3.02 & 3.35 & 3.60 & 3.77 & 3.47 & \\
\hline \multirow[t]{3}{*}{ Supporting } & $\begin{array}{l}\text { Erosion } \\
\text { prevention }\end{array}$ & 3.2 & 2.5 & 2.2 & 2.1 & 2.0 & 1.9 & 2.2 & 2.4 & 2.6 & 2.34 & \multirow[t]{3}{*}{4} \\
\hline & $\begin{array}{l}\text { Place for } \\
\text { wildlife } \\
\text { (Habitat) }\end{array}$ & 4.1 & 4.5 & 3.8 & 3.9 & 4.1 & 4.2 & 4.1 & 3.9 & 3.8 & 4.14 & \\
\hline & $\begin{array}{l}\text { Average } \\
\text { importance } \\
\text { of SESs }\end{array}$ & 3.65 & 3.50 & 3.0 & 3.0 & 3.05 & 3.05 & 3.15 & 3.15 & 3.2 & 3.24 & \\
\hline \multirow[t]{4}{*}{ Cultural } & $\begin{array}{l}\text { Spiritual } \\
\text { and cultural } \\
\text { value }\end{array}$ & 4.3 & 4.5 & 4.0 & 4.1 & 4.4 & 3.5 & 3.9 & 3.4 & 3.2 & 3.92 & \multirow[t]{4}{*}{3} \\
\hline & $\begin{array}{l}\text { Local } \\
\text { customs }\end{array}$ & 3.5 & 3.8 & 3.2 & 3.5 & 3.7 & 3.2 & 3.5 & 3.1 & 3 & 3.38 & \\
\hline & $\begin{array}{l}\text { Aesthetic } \\
\text { value }\end{array}$ & 2.8 & 3.1 & 2.3 & 2.1 & 2.7 & 2.6 & 2.5 & 2.7 & 2.9 & 2.63 & \\
\hline & $\begin{array}{l}\text { Average } \\
\text { importance } \\
\text { of CESs }\end{array}$ & 3.53 & 3.80 & 3.16 & 3.23 & 3.6 & 3.1 & 3.3 & 3.06 & 3.03 & 3.31 & \\
\hline
\end{tabular}


Provisioning ecosystem services was given highest importance (ranked 1) followed by regulating ESs (ranked 2), cultural ESs (ranked 3) and supporting ESs (ranked 4), respectively (Table 3). The perceived importance of ESs varies on the basis of gender, age and educational level of the tribal households. For example, in case of gender, female perceived more importance (4.54) to provisioning ESs as compared to male (4.30). The female are directly dependent of various services provided by local ecosystems (Figure 3 (a), (c) (f) and (h)). Age groups ranging from 21 to 60 are relatively highly dependent on provisioning ESs (4.20) as compared to other age groups (Figure $3(a),(f)$ and $(h)$ ). On the other hands, in case of regulating ESs, male perceived more importance (3.80) than female (3.70) due relatively better understanding the role of ESs in regulating environment. The livelihood pattern the tribal households largely depend on the direct benefits obtained from local ecosystems (Fig 3). Basic needs of the tribal households were significantly influenced by the services of the local ecosystems, tribal's reported.

Fuel wood was given highest priority (98\%) by the tribal households followed by water (drinking and bathing), main food, material for house and wild edible plants, respectively (Fig 4). Provisioning ESs, crucial for the livelihood of the tribal households was also vulnerable due to socio-economic transformation and climate change. For example, water bodies were most vulnerable due to irregularities of rainfall and most of the water bodies get dried up during summer season. The tribal households use polluted water for their daily purposes. Most of the tribal households were directly and indirectly dependent on agricultural activities and these agricultural lands were the basic sources of food (such as rice, vegetables). However, in recent past, most of the agricultural lands were kept as fallow due to lack of proper infrastructures and economic support (for example high price of fertilizers). Thus, the sources having provisions of ESs became vulnerable in tribal dominated ecological landscapes.

\subsection{Impact of socio-demographic attributes on ESs valuation}

The importance along with dependency of people on ESs was largely influenced by socio-demographic attributes of the households such as age, gender, educational level, occupation. Krushkal-Wallis test was significant for provisioning ESs for gender, education and occupation ( $\mathrm{p}$ <.05). Female (4.74) opted high importance to provisioning ESs as compared to male (4.10). Higher SD in case of male showed that there was higher variability of importance of provisioning ESs as compared to female. From the field survey, it was observed that women were primarily responsible for household management and therefore attached more importance to provision ecosystem services (Fig 3 a, c, f and h).

Educational level was important for determining the significant differences for the importance of provisioning ecosystem services. The importance of ESs decreased with increasing educational level i.e. 3.00 (at collage level) to 4.62 (illiterate). The illiterate in general were having fewer opportunities for income generation than literate. Moreover, illiterate had less voice in public and also having low social acceptance beside their sacredness to be public. The overall behavior and opportunities to illiterate leads to low entitlement and deprivation for livelihood and thus has high importance for provisioning service. No significant differences of provisioning ESs were observed for age classes due to the critical role of provision services for overall welfare of household. Therefore, irrespective of the differential age groups, the households were attaching more or less equal importance to provisioning ESs. Significant differences of importance perceived by the respondents were recorded for occupational status. Result showed that most of the respondents were engaged with primary economic activities (particularly agricultural activities). Agricultural labor, cultivators, daily workers, housewife valued more to provisioning ESs due to their direct dependency on the ecological landscapes. Only results of the provisioning ESs were discussed due to (i) higher dependency of households on ESs and (ii) no significant differences were found in case of perceived importance of other ecosystem services. Therefore, the importance of provisioning ESs was varied with inter-educational, inter-occupational and inter-gender difference, respectively. The significance of provisioning ESs supports that overall the socio-demographic attributes had a crucial role to perceive the importance of ESs (Table 4).

Table 4: Perceived importance of ESs based on socio-economic profile of the respondents 


\begin{tabular}{|c|c|c|c|c|c|c|c|c|c|}
\hline \multirow[b]{2}{*}{ Factors } & \multirow[t]{2}{*}{ Sub-indicator } & \multicolumn{2}{|l|}{ PEs } & \multicolumn{2}{|l|}{ REs } & \multicolumn{2}{|l|}{ SEs } & \multicolumn{2}{|l|}{ CEs } \\
\hline & & Mean & SD & Mean & SD & Mean & SD & Mean & SD \\
\hline \multirow[t]{3}{*}{ Gender } & Male & 4.10 & 0.57 & 3.04 & 1.79 & 1.46 & 2.02 & 2.16 & 1.95 \\
\hline & Female & 4.74 & 0.23 & 2.96 & 1.75 & 1.40 & 2.04 & 2.32 & 2.08 \\
\hline & $P$ value & 0.018 & & 0.945 & & 0.964 & & 0.90 & \\
\hline \multirow[t]{6}{*}{ Educational level } & Primary & 4.15 & 0.52 & 2.44 & 1.42 & 1.28 & 1.80 & 1.90 & 1.67 \\
\hline & Secondary & 4.01 & 0.55 & 2.70 & 1.63 & 1.32 & 1.80 & 2.02 & 1.82 \\
\hline & H.S. & 3.81 & 0.72 & 2.90 & 1.69 & 1.32 & 1.75 & 1.88 & 1.64 \\
\hline & College & 3.00 & 0.40 & 3.24 & 1.90 & 1.34 & 1.75 & 1.86 & 1.61 \\
\hline & Illiterate & 4.62 & 0.49 & 3.18 & 1.74 & 1.56 & 2.03 & 2.64 & 2.34 \\
\hline & $P$ value & 0.001 & & 0.961 & & 0.999 & & 0.956 & \\
\hline \multirow[t]{4}{*}{ Age range } & $20-40$ & 4.04 & 0.69 & 2.64 & 1.62 & 1.2 & 1.73 & 1.42 & 0.87 \\
\hline & $41-60$ & 4.42 & 0.46 & - & - & - & - & 1.98 & 1.20 \\
\hline & $>60$ & 4.27 & 0.55 & 2.66 & 1.63 & 1.7 & 2.35 & 2.40 & 1.86 \\
\hline & $P$ value & 0.47 & & 0.51 & & 0.712 & & 0.008 & \\
\hline \multirow[t]{6}{*}{ Occupation } & Agriculture labor & 4.54 & 0.31 & 3.36 & 1.88 & 1.56 & 2.00 & 2.40 & 2.15 \\
\hline & Wage labour & 4.17 & 0.67 & 3.04 & 1.67 & 1.12 & 1.40 & 2.44 & 2.19 \\
\hline & Cultivator & 4.28 & 0.36 & 2.98 & 1.82 & 1.3 & 1.66 & 2.38 & 2.19 \\
\hline & House wife & 4.28 & 0.56 & 2.66 & 1.51 & 1.1 & 1.37 & 2.70 & 2.40 \\
\hline & Student & 3.37 & 0.56 & 2.94 & 1.67 & 1.38 & 1.77 & 1.80 & 1.55 \\
\hline & $P$ value & 0.002 & & 0.98 & & 0.99 & & 0.97 & \\
\hline
\end{tabular}

Where, $\mathbf{N}=$ Number of respondents; $\mathbf{S D}=$ Standard Deviation; Bold color indicates significant at 0.05 levels.

The average perceived importance of ESs was highest for provisioning ecosystem services (4.42) followed by regulation ecosystem services (3.00) and cultural ecosystem services (2.24), respectively (Table 4). Female valued more to provisioning ecosystem services as compared to male. Average perceived importance of provisioning ecosystem services was 3.92 and highest importance was given by illiterate (4.62) followed by primary, secondary, higher secondary and collage respectively. In case of age and occupational status also, the perceived importance of provisioning ecosystem service was highest in comparison to other ecosystem services. Therefore, it is clear that the perceived importance of ecosystem services was largely influenced by socio-demographic attributes of the tribal community (Table 4).

\subsection{Linkage between ESs and IEK in tribal ecological landscapes}

It was observed during the interactions with the informants during survey that IEK practices were in practice at households and community level to manage ESs though their socio-cultural mechanism. The IEK practices were manifested in their routine livelihoods such as framings, collections as well as use of plants, climate prediction. Tribal were dependent on ecological units for variety of purposes such as plant species for food (root and tubers, leafy vegetables, fruits), fiber, fodder and timber and building materials besides naturally occurring insecticides, gum, resins, dyes. Therefore, IEK has the potential to increase well-being by ensuring the smooth flow of ESs from ecosystems besides promoting social resilience and fostering social cohesion, tribal reported. On the basis of functions and characteristics the IEK practices were categorize into four main domains. These IEK practices were performing a significant role for livelihood sustainability of the tribal people, and sustainable conservation and management of natural resources. The tribal people collect fuels from the local forest, build houses with thatches (collected from palm trees, date palm), collected fodders, the water bodies are used for bathing, washing as well as for irrigational purposes (Figure 3). This clearly denotes the fact 
that daily livelihood of the tribal people were largely influenced by the services from the local ecosystems. The IEK practices applied at households and community level were crucial for sustainable management of local ecosystems. No killing of animal, destruction of plant species, conservation of trees, sacred groves have significant ecological value and followed by tribal through IEK practices. The IEK practices, implied with indefinite and intimate relationship with the belief system by tribal for biodiversity conservation and maintenance of ecosystems were grounded in a series of customs, rituals and rules and regulations (Table 5). However, the tribal communities were unable to appreciate the ecological significance of IEK practices.

\subsubsection{IEK practices in the form of taboos and totems}

During survey, it was observed that taboos and totems applied at households and community level were for the conservation of resources i.e. managing the overharvesting of provisioning ESs leading to future use. Moreover, the villagers reported that the IEK promotes and support for thriving of species (biodiversity) through restorations of animal and plant species. As per the interactions with the informants, it was found that many taboos such as prohibiting the killing of various animals as well as cutting of plants species with linking the provisions with local deities, were under practice. From the field survey, it was observed that tribal communities had practicing several taboos and totems. For example, (i) among Hansda community, ducks (Anatidae) was considered as god ad they were not consumed by the community and even no harm was being made to ducks. (ii) Among 'Soren' community, pigeons (Columbidae) was considered as gods (iii) among 'Pauriya' community, shoal fishes (Channa striata) was treated as deity. Apart from animal species, plant species were also prioritized within taboos and totems from the perspectives of traditional belief systems. For example, Betel nut (Areca catechu), Palash tree (Butea monosperma) and Banyan trees (Ficus benghalensis) were worshiped as god and used as medical plants. This clearly denotes that taboos and totems were inherently linked with the conservation biological diversity (both animals and plant species) and management of ecosystems. Indigenous conservation of these plant species not only help to conserve bio-diversity rather act as 'safety net' and 'resources ground' to the tribal communities.

In tribal landscapes, several sacred places (locally known as 'Jaherthan' and 'Majhithan') were located within ecological landscapes (such as forests, bushes). The accesses to these sacred places were strictly prohibited and people were not allowed to collect fuels or any services from those patches. These sacred places were considered to be the abode of different deity who not only protect the villages from the natural calamities, diseases and famine but also provides mental well-being to the tribal communities. Entrance to these sacred places was believed to harm for trespassers. Thus the respect as well as fear of these belief systems have crucial role for forests as well as ecological patches conservation.

\subsubsection{IEK practices in the form of customs and rituals}

Customs and rituals were also part of IEK practices performed by the tribal communities. Customs or rituals were the particular social norms, practices as well as ceremonies maintained by households or communities for sustainability of the ecological resources, tribal reported. The IEK practices in the form of customs and rituals were performed either to enhance accessibility to ESs or to raise productivity of land through symbolically appreciating the importance of ecosystems. For example, celebration of a ceremony during harvesting new crops (popularly known as 'noban' performed at the households' level) and worshiping of gods during drought for rains or good crop productions were in practice. Such ceremonies at household or community level were ensures an equitable and flexible distribution of resources, and also ensures harmony among the people, the environment and the God which was considered to enhance ESs and land productivity. During ceremony for rain, frogs were married (male and female frogs) at community level and pray to god for rain as well as high agricultural productivity. Medical plants such as Tulshi (Ocimum tenuiflorum), Dhutura (Datura stramomnium) were used for various common diseases such as cough, cold, headache, ear pain etc for their health well-being. An elderly tribe remarked, "we rarely visit hospitals or doctors as we use local medical plants for our health problems such as fever, cold, pains". This eco-spiritual tradition among tribal communities have immense ecological significance (may be termed as invisible ecological benefits as tribal communities were unaware about ecological significance of these traditions). IEK has significant contribution to the conservation of ecology of the local ecosystems. The conservation of provisioning, regulating and cultural ecosystem services were closely linked with the different IEK practices implemented at tribal households as well as community level. Therefore, a strong nexus between IEK and socio-ecological system in tribal dominated ecological landscapes were observed (Table 5).

Table 5: Linkages between IEK and ESs with their socio-ecological significance 


\begin{tabular}{|c|c|c|c|}
\hline $\begin{array}{l}\text { Major domain } \\
\text { of IEK }\end{array}$ & IEK practices & ESs & Socio- ecological significance \\
\hline \multirow[t]{5}{*}{$\begin{array}{l}\text { Taboos and } \\
\text { totems }\end{array}$} & No killing of kind animal species & $\begin{array}{l}\text { PESs, } \\
\text { CESs }\end{array}$ & $\begin{array}{l}\text { Conserve biological diversity of the local } \\
\text { environment. }\end{array}$ \\
\hline & $\begin{array}{l}\text { No cutting down of specific tree } \\
\text { species }\end{array}$ & $\begin{array}{l}\text { PESs, } \\
\text { RESs }\end{array}$ & $\begin{array}{l}\text { Regulate local climate and conserve several } \\
\text { vulnerable plant and medical species. }\end{array}$ \\
\hline & $\begin{array}{l}\text { No cutting down of sacred or } \\
\text { medical plants during farming }\end{array}$ & $\begin{array}{l}\text { PESs, } \\
\text { RESs }\end{array}$ & $\begin{array}{l}\text { Conserve vulnerable and valuable species. Thus, } \\
\text { protect biological diversity. }\end{array}$ \\
\hline & No fishing (eating) any day & $\begin{array}{l}\text { PESs, } \\
\text { PESs }\end{array}$ & $\begin{array}{l}\text { Conserve fish species and promotes livelihood } \\
\text { sustainability. }\end{array}$ \\
\hline & $\begin{array}{l}\text { Prohibition to collect fuel from } \\
\text { sacred areas }\end{array}$ & $\begin{array}{l}\text { PESs, } \\
\text { CESs }\end{array}$ & $\begin{array}{l}\text { Protect forest ecosystems and conserve various } \\
\text { animal and plant species. }\end{array}$ \\
\hline \multirow[t]{3}{*}{$\begin{array}{l}\text { Customs and } \\
\text { rituals }\end{array}$} & Rainmaking ceremony & $\begin{array}{l}\text { RESs, } \\
\text { CESs }\end{array}$ & $\begin{array}{l}\text { Decreases drought vulnerability and promote growth } \\
\text { of plant species. }\end{array}$ \\
\hline & Usage of Indigenous medicines & $\begin{array}{l}\text { PESs, } \\
\text { CESs }\end{array}$ & $\begin{array}{l}\text { Conserve vulnerable as well as valuable plant } \\
\text { species. Preserve biodiversity. }\end{array}$ \\
\hline & Festivals during harvesting season & CESs & Enhance social cohesion and ecological integrity. \\
\hline \multirow[t]{3}{*}{$\begin{array}{l}\text { Rules and } \\
\text { regulation }\end{array}$} & $\begin{array}{l}\text { No harvesting without permission } \\
\text { from individuals }\end{array}$ & $\begin{array}{l}\text { PESs, } \\
\text { RESs }\end{array}$ & $\begin{array}{l}\text { Enhance social relations and ecological } \\
\text { sustainability. }\end{array}$ \\
\hline & $\begin{array}{l}\text { Permission from the chief to farm } \\
\text { agricultural land }\end{array}$ & PESs, & $\begin{array}{l}\text { Promote biological diversity and enhance social well- } \\
\text { being. }\end{array}$ \\
\hline & $\begin{array}{l}\text { Hunting of pregnant animals is } \\
\text { strictly prohibited }\end{array}$ & $\begin{array}{l}\text { PESs, } \\
\text { RESs }\end{array}$ & $\begin{array}{l}\text { Conserve biological diversity and enhance livelihood } \\
\text { sustainability. }\end{array}$ \\
\hline \multirow[t]{3}{*}{$\begin{array}{l}\text { Indigenous } \\
\text { protected areas }\end{array}$} & Forests & $\begin{array}{l}\text { RESs, } \\
\text { CESs }\end{array}$ & $\begin{array}{l}\text { Regulate the local climate and enhance the cultural } \\
\text { value of ESs }\end{array}$ \\
\hline & Water sites & $\begin{array}{l}\text { PESs, } \\
\text { RESs, } \\
\text { CESs }\end{array}$ & $\begin{array}{l}\text { Regulate local climate, livelihood of the people and } \\
\text { increase cultural value of ESs }\end{array}$ \\
\hline & Sacred groves & $\begin{array}{l}\text { RESs, } \\
\text { CESs }\end{array}$ & $\begin{array}{l}\text { Preserve several vulnerable species, medical plants } \\
\text { and valuable animals and plants. }\end{array}$ \\
\hline
\end{tabular}

ESs= ecosystem services; PESs= provisioning ecosystem services; RESs= regulating ecosystem services; $\mathrm{SESs}=$ supporting ecosystem services; $C E S s=$ cultural ecosystem services

\subsubsection{IEK practices in the form of rules and regulations}

IEK practices in the form of rules and regulations were mainly related to the use and non use of various ecosystem services. Various rules and regulations were enacted by the villagers to protect ESs (though it was not categorically recognized by the tribal households). Strict rules were imposed on households and punishments were levied for violating such rules and regulations. In the study villages, it was observed that killing of pregnant animals were strictly prohibited and punishable, as well. Such rules and regulations were not only significant for bio-diversity conservation rather crucial for environmental sustainability. Particularly, animals like ducks, pigeons were not hunted rather preserved from spiritual perspectives. Thus, conservation of these animals was not only significant for bio-diversity conservations but also economic well-being of the tribal communities. The ducks were reared and eggs were sold to local markets (even ducks). Thus, IEK practices in the form of rules and regulations have twin benefits on tribal communities i.e. environmental and economic well-being, respectively.

Apart from animal species, there were strict restrictions on the use of community resources such as water bodies, patches of trees. One needs to seek permission from the others (chief of the village many times) to use these resources. For example, the leaves and branches of the trees were not used from the restricted areas (such as sacred sites, community forest resources. Capturing fishes from the community ponds or water bodies without permission was punishable. During interactions with a respondent, it was made clear that, "violation of rules and regulations i.e. use of resources from the restricted areas may cause fines".

Page $11 / 25$ 


\subsubsection{IEK practices in the form of Indigenous protected areas}

Tribal worship, respect and nurture the nature. IEK practices in the form of indigenous protected areas were applied to protect specific local ecological landscapes such as water bodies, sacred groves, trees, bushes etc. There were few tress particularly Banyan tress (Ficus benghalensis), Sal trees (Shorea robusta) which were worshiped on daily basis. These ecological landscapes were protected, however most of the time, tribal communities were unaware about the role of such protection to their environment well-being (Table 6).

Table 6: Rules and regulations for performance of activities in and around sacred sites

\begin{tabular}{|c|c|c|}
\hline \multirow[t]{2}{*}{ Activity } & \multicolumn{2}{|c|}{ Applicability of activities } \\
\hline & Yes & No \\
\hline Deforestation in and around the sacred sites & - & $\sqrt{ }$ \\
\hline Human disturbances in and around the sacred sites & - & $\sqrt{ }$ \\
\hline Collection of any resources from the sacred sites & - & $\sqrt{ }$ \\
\hline Fence around the sacred sites & $\sqrt{ }$ & - \\
\hline Walking people in sacred sites & - & $\sqrt{ }$ \\
\hline Worshiping the sacred sites & $\sqrt{ }$ & \\
\hline Guards in sacred sites & - & $\sqrt{ }$ \\
\hline Taking blessings of newly married couple from the sacred sites & $\sqrt{ }$ & - \\
\hline
\end{tabular}

In the study villages, there were strict restrictions on entrance and use of these sacred places so that the places should be protected and conserved, tribal reported. Permissions were needed from the villagers or chief of the village to enter into the sacred places. Thus, protection of scared groves was a unique example of community based conservation of nature as well as ESs without any moral supports. Many times, plots of ecological landscapes were treated as sacred places and known as 'Jaherthan' and 'Majhithan' to the local people. Most of indigenous sacred places were preserved around forested areas, bushes, water sites and even inaccessible forested areas. These sacred indigenous ecological landscapes were classified and barricaded by barriers (made of bamboo, bricks). The lists of activities observed in and around the sacred sites are presented in Table 6.

\subsection{Assessment IEK awareness and compliance of the tribal communities}

The field survey resulted higher discrepancies between IEK awareness and compliance among the respondents (Figure 6). The IEK in respect of indigenous protected areas was having high awareness (87\%) and compliance (60\%), respectively. Eighty (80\%) communities were awareness and $57 \%$ had compliance (57\%) for Taboos and totems and $71 \%$ was aware for IEK of customs and rituals with $45 \%$ compliances, however, relatively communities was less aware for rules and regulations and also for their compliances, respectively (Figure 6).

\section{Discussion}

The tribal households were largely dependent on provisioning ESs for their daily livelihood. The socio-demographic attributes were important and significant for utilizing the ESs for household livelihood. Indigenous ecological knowledge is closely linked with ESs (Figure 5) and directly and indirectly influenced the use and protection of flow of ESs as per the local socio-cultural norms of the tribal (Berkes et al., 2000; Colding and Folke, 2001). Many indigenous communities in different parts of the world use indigenous knowledge to regulate and management of flow of ESs (Shackleton and Shackleton, 2018; Boafo et al., 2016a; Saylor et al., 2017; Cebrián-Piqueras et al., 2020; Parrotta et al., 2016; Stori et al., 2019). The result recorded reflected the strong socio-ecological synergy within the tribal IEK practices. The tribal community protects and conserves specific ecological landscapes such as sacred groves, water sites and fallow land due to its unique linkages with socio-ecology by imposing various rules and regulation with strict restrictions to avoid deterioration of indigenous protected areas. Moreover protections of ecological landscapes are crucial for socioeconomic, cultural as well as environmental well-being of the communities (Boafo et al., 2016a). Strong associations between IEK 
practice and ESs or conservation of environment are reported in many evaluations as per the indigenous belief system of tribal (Boafo et al., 2014); protection and conservation of sacred groves, fallow land, bushes (Millar, 2004).

Management of ESs through IEK practices was linked with human well-being such as security, basic materials for life, health, good social relation and freedom of choice. The linkages had varied intensity (as weak, medium and high) for achieving the household welfare depending upon the requirement and availability and accessibility of resources and therefore contribute for provision of households. The trees or water sites or patches of tress were worshipped for generation to generation though IEK practices therefore conserving the resources and also enriching the culture for environmental sustainability.

Indigenous ecological knowledge contributes significantly to sustain livelihood of the stakeholders, to restore ecosystems services and bio-diversity and also for resilience of the socio-ecological system (Mcdade et al., 2008; Reyes-Garcia et al., 2014; GomezBaggetun et al., 2012) (Figure 7). IEK can contribute for managing and ensuring the sustainable utilization of resources and management of ecosystem for flows of ESs under the current unprecedented deterioration and degradation of ESs and biodiversity (Boadfo et al., 2016a). However, indigenous ecological knowledge are degrading rapidly due to variety of reasons as (i) loss of local languages (McCarter and Gavin, 2011; Reyes-Garcia et al., 2013); (ii) alteration of land use (Kingsbury, 2001; Gray et la., 2013) (iii) integration of marketing system (Godoy et al., 2005; Reyes-Garcia et al., 2005); and (iv) industrialization and rapid urbanization (Turner and Turner, 2008; Gomez-Baggethun et al., 2010b) respectively. Therefore, role and use of indigenous ecological knowledge has emerged as one of the research themes for sustaining socio-ecological resilience due to the global environmental change and deteriorations of ecosystem (MEA, 2005). Moreover, indigenous ecological knowledge are important (i) a source of inspiration for designing environmental management and (ii) restoration and ecological modeling for sustainability.

The main focus of IEK is ecological knowledge maintained by local cultures and closely linked with local ecosystems transferring from one generation to provide a strong support and knowledge for environmental sustainability and natural resource conservation and management on long term basis (Menzies and Butler, 2006). World Commission on Environment and Development (1987) stated in Our Common Future that "larger society could learn a great deal from indigenous skills of indigenous cultures in sustainably managing very complex ecological systems". IEK of the indigenous people builds an ecologically balanced interaction and sustains sustainability of the environment. Therefore, traditions and practices of IEK is becoming a prominent fields and wisdom regarding design of ecosystems and sustainable use of resources (Menzies and Butler, 2006; Armstrong et al., 2007).

Sustainable environmental management requires immediate and adequate consideration of various services provided by ecosystems. This is highly imperative as ESs are crucial to human well-being and social welfare (Colding, 2001; Mascarenhas et al., 2014) however integrate of ESs in environmental management is lacking in decision making framework. Therefore, highlighting the significance of the benefits, valuing of ESs is crucial (Elliott, 2011). Particularly in developing countries, no emphasis is attached on the functional value of ESs during developmental planning and policies. Therefore, the current research will guide to integrate ESs in environmental management in development framework (Figure 7).

\section{Conclusion}

The present study dealt with the assessment the nexus between indigenous ecological knowledge (IEK) and Ecosystem Services (ESs) from socio-ecological perspectives in tribal dominated landscapes. The analysis showed that provisioning ESs were the prominent ESs to which tribal households were largely dependent due to direct benefits and higher dependency for their daily livelihood. Moreover, socio-demographic attributes (such as gender, age, educational level, occupations) of the tribal households have immense impact on attribution of ecosystem, services. Various type of IEK practices in the form of taboos and totems; customs and rituals; rules and regulations and indigenous protected areas were integral part of the tribal cultures and had crucial role for the conservation as well as management of ESs for ensuring the overall household welfare. Therefore, socio-ecological nexus between indigenous ecological knowledge (IEK) and ESs can guide for significant opportunities to prioritize the IEK practices for better management of ESs by making strategic planning for ecosystem management. The findings of the study also provide feedbacks to the government policies and supports for implementing various rules and regulations by the government through integration of IEK practices for ecosystem management. The scientifically integration of the IEK in decision making framework may support for sustainable management of ESs as well as to enhance well-being of the people.

\section{Declarations}




\section{Ethical Approval}

"Not applicable"

\section{Consent to Participate}

All participants were provided their consent for participating into the interview.

\section{Consent to Publish}

"Not applicable"

\section{Author Contribution}

$M D$, SS and AD conceptualise and designed the study; MD collected and analysed the data with the support of RP and written the paper; MD, AD, SS and RP interpreted the analysis. MD, AD, SS and RP read and modified the paper. All four have contributed extensively for data interpretation and discussions. All authors consented for the publication.

\section{Funding}

No funding was received for the study.

\section{Competing Interests}

The authors declare that they have no competing interests.

\section{Availability of Data and Materials}

The datasets used during the current study are available from the corresponding author on reasonable request.

\section{Acknowledgements}

We would like to extend hearty acknowledgement to the respondents of the villages for their consent to participate in the study and cooperation during field survey. Special thanks to Mr Pargon Henbram and Mr Ashoke Rajbanshi for their support for the study. We are also extremely thankful to Asish Mandal, Himadri Barman, Abdur Rejjack, Rejaul Houque, Ketan Das and Subrata Mandal for their assistance during field survey.

\section{References}

Akwetaireho, S., \& Getzner, M. (2010). Livelihood dependence on ecosystem services of local residents: a case study from Mabamba Bay wetlands (Lake Victoria, Uganda). International Journal of Biodiversity Science, Ecosystem Services \& Management, 6(1-2), 7587.

Armstrong, M., Kimmerer, R. W., \& Vergun, J. (2007). Education and research opportunities for traditional ecological knowledge. Frontiers in Ecology and the Environment, 5(4), 1-3.

Asmamaw, L. B., Mohammed, A. A., \&Lulseged, T. D. (2011). Land use/cover dynamics and their effects in the Gerado catchment, northeastern Ethiopia. International Journal of Environmental Studies, 68(6), 883-900.

Berkes, F., Folke, C., \& Colding, J. (Eds.). (2000). Linking social and ecological systems: management practices and social mechanisms for building resilience. Cambridge University Press.

Bhatta, L. D., Chaudhary, S., Pandit, A., Baral, H., Das, P. J., \& Stork, N. E. (2016). Ecosystem service changes and livelihood impacts in the Maguri-Motapung Wetlands of Assam, India. Land, 5(2), 15.

Boafo, Y. A., Saito, O., Jasaw, G. S., Otsuki, K., \& Takeuchi, K. (2016a). Provisioning ecosystem services-sharing as a coping and adaptation strategy among rural communities in Ghana's semi-arid ecosystem. Ecosystem Services, 19, 92-102. 
Boafo, Y. A., Saito, O., Kato, S., Kamiyama, C., Takeuchi, K., \& Nakahara, M. (2016b). The role of traditional ecological knowledge in ecosystem services management: the case of four rural communities in Northern Ghana. International Journal of Biodiversity Science, Ecosystem Services \& Management, 12(1-2), 24-38.

Byg, A., \& Balslev, H. (2004). Factors affecting local knowledge of palms in Nangaritza Valley in South-Eastern Ecuador. Journal of Ethnobiology, 24(2), 255-278.

Calvet-Mir, L., Gómez-Baggethun, E., \& Reyes-García, V. (2012). Beyond food production: Ecosystem services provided by home gardens. A case study in VallFosca, Catalan Pyrenees, Northeastern Spain. Ecological Economics, 74, 153-160.

Campbell, E. T. (2018). Revealed social preference for ecosystem services using the eco-price. Ecosystem Services, 30, $267-275$.

Castro, A. J., Martín-López, B., García-Llorente, M., Aguilera, P. A., López, E., \& Cabello, J. (2011). Social preferences regarding the delivery of ecosystem services in a semiarid Mediterranean region. Journal of Arid Environments, 75(11), 1201-1208.

Cebrián-Piqueras, M. A., Filyushkina, A., Johnson, D. N., Lo, V. B., López-Rodríguez, M. D., March, H., ... \& Plieninger, T. (2020). Scientific and local ecological knowledge, shaping perceptions towards protected areas and related ecosystem services. Landscape Ecology, 35(11), 2549-2567.

Chan K, Guerry A, Balvanera P, Klain S, Satterfield T, Basurto X, ...Woodside U. (2012a). Where are Cultural and Social in Ecosystem Services? A Framework for Constructive Engagement BioScience 62:744-756.10.1525/bio.2012.62.8.7.

Chan KM, Satterfield T, Goldstein J. (2012b). Rethinking ecosystem services to better address and navigate cultural values. Ecological Econ. 74:8-18.

Christina R. Saylor, Dr. Kamal A. Alsharif \& Hannah Torres (2017) The importance of traditional ecological knowledge in agroecological systems in Peru, International Journal of Biodiversity Science, Ecosystem Services \& Management, 13:1, 150-161, DOI: 10.1080/21513732.2017.1285814.

Ciftcioglu, G. C. (2017). Social preference-based valuation of the links between home gardens, ecosystem services, and human wellbeing in Lefke Region of North Cyprus. Ecosystem services, 25, 227-236.

Colding, J. (1998). Analysis of hunting options by the use of general food taboos. Ecological Modelling, 110(1), 5-17.

Colding, J., \&Folke, C. (2001). Social taboos:"invisible" systems of local resource management and biological conservation. Ecological applications, 11(2), 584-600.

Das A, Ramkrushna GI, Choudhury BU, Munda GC, Patel DP, Ngachan SV, Ghosh PK, Tripathi AK, Das S, Kumar M. (2012). Natural resource conservation through indigenous farming systems: wisdom alive in north-east India. Indian J Tradit Know 11: 505-513.

Daw, T. I. M., Brown, K., Rosendo, S., \& Pomeroy, R. (2011). Applying the ecosystem services concept to poverty alleviation: the need to disaggregate human well-being. Environmental Conservation, 38(4), 370-379.

de Groot, R.S., Wilson, M.A., Boumans, R.M.J., (2002). A typology for the classification, description and valuation of ecosystem functions, goods and services. Ecol. Econ. 41, 393-408.

Deng, J., Sun, P., Zhao, F., Han, X., Yang, G., \&Feng, Y. (2016). Analysis of the ecological conservation behavior of farmers in payment for ecosystem service programs in eco-environmentally fragile areas using social psychology models. Science of the Total Environment, 550, 382-390.

Deng, X., \& Gibson, J. (2018). Sustainable land use management for improving land eco-efficiency: a case study of Hebei, China. Annals of Operations Research, 1-13.

Elliott, M., \& Whitfield, A. K. (2011). Challenging paradigms in estuarine ecology and management. Estuarine, Coastal and Shelf Science, 94(4), 306-314. 
Fisher B, Turner RK, Morling P. (2009). Defining and classifying ecosystem services for decision making. Ecological Econ. 68:643653.

Gadgil, M., Berkes, F., \&Folke, C. (1993).Indigenous knowledge for biodiversity conservation. Ambio, 151-156.

Geronimo MC, Cabansag MGS, Reyes AS. (2016). Indigenous utilization of resources and conservation practices of the Agta of Lupigue, Iligan City, Isabela, Philippines. Intl J Educa Stud 8 (2). www.mindamasjournals.com/index.php/educare.

Godoy, R., Reyes-García, V., Byron, E., Leonard, W. R., \& Vadez, V. (2005). The effect of market economies on the well-being of indigenous peoples and on their use of renewable natural resources. Annu. Rev. Anthropol., 34, 121-138.

Gómez-Baggethun, E. R. I. K., Mingorria, S., Reyes-García, V. I. C. T. O. R. I. A., Calvet, L., \& Montes, C. (2010a). Traditional ecological knowledge trends in the transition to a market economy: empirical study in the Doñana natural areas. Conservation Biology, 24(3), 721-729.

Gómez-Baggethun, E., De Groot, R., Lomas, P. L., \& Montes, C. (2010b). The history of ecosystem services in economic theory and practice: from early notions to markets and payment schemes. Ecological economics, 69(6), 1209-1218.

Gómez-Baggethun, E., Gren, Å., Barton, D. N., Langemeyer, J., McPhearson, T., O'farrell, P., ... \& Kremer, P. (2013). Urban ecosystem services. In Urbanization, biodiversity and ecosystem services: Challenges and opportunities (pp. 175-251). Springer, Dordrecht.

Gómez-Baggethun, E., Reyes-García, V., Olsson, P., \& Montes, C. (2012). Traditional ecological knowledge and community resilience to environmental extremes: A case study in Doñana, SW Spain. Global Environmental Change, 22(3), 640-650.

Gray, M., Gordon, J. E., \& Brown, E. J. (2013). Geodiversity and the ecosystem approach: the contribution of geoscience in delivering integrated environmental management. Proceedings of the Geologists' Association, 124(4), 659-673.

Halim AAB, Othman N, Ismail SR, Jawan JA, Ibrahim NN. (2012). Indigenous knowledge and biodiversity conservation in Sabah, Malaysia. Intl J Soc Sci Humanity 2 (2): 159-163.

Harisha RP, Padmavathy S, Nagaraja BC. (2015). Traditional Ecological Knowledge (TEK) and its importance in south India: perspective from local communities. Appl Ecol Env Res 14 (1): 311-326.

IPBES. (2016). About IPBES. Retrieved September 11, 2020, from http://www.ipbes.net/about-us

Johannes, R. E. (1998). The case for data-less marine resource management: examples from tropical nearshorefinfisheries. Trends in Ecology \& Evolution, 13(6), 243-246.

Joos-Vandewalle, S., Wynberg, R., \& Alexander, K. A. (2018). Dependencies on natural resources in transitioning urban centers of northern Botswana. Ecosystem Services, 30, 342-349.

Kelemen, E., García-Llorente, M., Pataki, G., Martín-López, B., \& Gómez-Baggethun, E. (2014).Non-monetary techniques for the valuation of ecosystem service. OpenNESS Reference Book.EC FP7 Grant Agreement, (308428), 4.

Kingsbury, N. D. (2001). Impacts of land use and cultural change in a fragile environment: indigenous acculturation and deforestation in Kavanayén, Gran Sabana, Venezuela. Interciencia, 26(8), 327-336.

Langemeyer, J., Gómez-Baggethun, E., Haase, D., Scheuer, S., \&Elmqvist, T. (2016).Bridging the gap between ecosystem service assessments and land-use planning through Multi-Criteria Decision Analysis (MCDA). Environmental Science \& Policy, 62, 45-56.

Laudari, D. (2010). Implication of traditional ecological knowledge on forest resource management. Himalayan Journal of Sociology and Anthropology, 4, 77-90.

Lele S, Springate-Baginski O, Lakerveld R, Deb D, Dash P. (2013). Ecosystem Services: Origins, Contributions, Pitfalls, and Alternatives. Conservation Soc 11:343.10.4103/0972-4923.125752.

MA (Millennium Ecosystem Assessment), 2005. Ecosystems and human well-being: Synthesis. Island Press, Washington, DC. 
Malik, J.; Bhatt, A.B. and Pandey R. (2016). Anthropogenic Disturbances and Their Impact on Vegetation in Western Himalaya, India. Journal of Mountain Science, 13(1): 69-82. DOI: 10.1007/s11629-015-3533-7.

Mascarenhas, A., Ramos, T. B., Haase, D., \& Santos, R. (2014). Integration of ecosystem services in spatial planning: a survey on regional planners' views. Landscape ecology, 29(8), 1287-1300.

McCarter, J., \& Gavin, M. C. (2011). Perceptions of the value of traditional ecological knowledge to formal school curricula: opportunities and challenges from Malekula Island, Vanuatu. Journal of ethnobiology and ethnomedicine, 7(1), 1-14.

McDade, T. W., Reyes-García, V., Tanner, S., Huanca, T., \& Leonard, W. R. (2008). Maintenance versus growth: investigating the costs of immune activation among children in lowland Bolivia. American Journal of Physical Anthropology: The Official Publication of the American Association of Physical Anthropologists, 136(4), 478-484.

Menzies, C.R., Butler, C., (2006). Understanding ecological knowledge. In: Menzies, C. (Ed.), Traditional Ecological Knowledge and Natural Resource Management. University of Nebraska Press, Lincoln, NE, pp. 1-20.

Miller, A. J., Chai, F., Chiba, S., Moisan, J. R., \& Neilson, D. J. (2004).Decadal-scale climate and ecosystem interactions in the North Pacific Ocean. Journal of Oceanography, 60(1), 163-188.

Obiora, A. C., \& Emeka, E. E. (2015). African indigenous knowledge system and environmental sustainability. International Journal of Environmental Protection and Policy, 3(4), 88-96.

Pandey R. (2009). Forest Resource Utilization by Tribal Community of Jaunsar. The Indian Forester, 135(5): $436-441$.

Pandey, R., Aretano, R., Gupta, A.K., Meena, D., Kumar, B., \& Alatalo, J.M. (2017). Agroecology as a Climate Change Adaptation Strategy for Smallholders of Tehri-Garhwal in the Indian Himalayan Region. Small-scale Forestry 16(1): 53-63. D0I 10.1007/s11842016-9342-1.

Parrotta, J., Yeo-Chang, Y., \& Camacho, L. D. (2016). Traditional knowledge for sustainable forest management and provision of ecosystem services. https://doi.org/10.1080/21513732.2016.1169580.

Rathore SS, Karunakaran K, Prakash B. (2010). Alder based farming system a traditional farming practices in Nagaland for amelioration of jhum land. Indian J Tradit Know 4: 677-680.

Reyes-García, V., Aceituno-Mata, L., Calvet-Mir, L., Garnatje, T., Gómez-Baggethun, E., Lastra, J. J., ... \& Pardo-de-Santayana, M. (2014). Resilience of traditional knowledge systems: The case of agricultural knowledge in home gardens of the lberian Peninsula. Global Environmental Change, 24, 223-231.

Reyes-García, V., Luz, A. C., Gueze, M., Paneque-Gálvez, J., Macía, M. J., Orta-Martínez, M., ... \& TAPS Bolivian Study Team. (2013). Secular trends on traditional ecological knowledge: An analysis of changes in different domains of knowledge among Tsimane'men. Learning and individual differences, 27, 206-212.Lopes, R., \& Videira, N. (2013). Valuing marine and coastal ecosystem services: an integrated participatory framework. Ocean \& Coastal Management, 84, 153-162.

Reyes-García, V., Vadez, V., Byron, E., Apaza, L., Leonard, W., Pérez, E., \& Wilkie, D. (2005). Market economy and the loss of ethnobotanical knowledge: Estimates from Tsimane'Amerindians, Bolivia. Current Anthropology, 46(4), 651-656.

Ruiz-Mallén I, Corbera E. 2013. Community-Based Conservation and Traditional Ecological Knowledge: Implications for SocialEcological Resilience. Ecol Soc 18:4.10.5751/ES-05867-180412.

Santos-Martin, F., Viinikka, A., Mononen, L., Brander, L., Vihervaara, P., Liekens, l., \&Potschin-Young, M. (2018).Creating an operational database for Ecosystems Services Mapping and Assessment Methods. One Ecosystem, 22831.

Saylor, C. R., Alsharif, K. A., \& Torres, H. (2017). The importance of traditional ecological knowledge in agroecological systems in Peru. International Journal of Biodiversity Science, Ecosystem Services \& Management, 13(1), 150-161. 
Schäfer, R. B., Bundschuh, M., Rouch, D. A., Szöcs, E., Peter, C., Pettigrove, V., ..\&Kefford, B. J. (2012). Effects of pesticide toxicity, salinity and other environmental variables on selected ecosystem functions in streams and the relevance for ecosystem services. Science of the Total Environment, 415, 69-78.

Shackleton, S. E., \& Shackleton, R. T. (2018). Local knowledge regarding ecosystem services and disservices from invasive alien plants in the arid Kalahari, South Africa. Journal of arid environments, 159, 22-33.

Smith, L.M., Case, J.L., Smith, H.M., Harwell, L.C., Summers, J.K., 2013. Relating ecosystem services to domains of human well-being: foundation for a US index. Ecol. Ind. 28, 79-90.

Stori, F. T., Peres, C. M., Turra, A., \& Pressey, R. L. (2019). Traditional ecological knowledge supports ecosystem-based management in disturbed coastal marine social-ecological systems. Frontiers in Marine Science, 6, 571.

Turner, N. J., \& Turner, K. L. (2008). "Where our women used to get the food": cumulative effects and loss of ethnobotanical knowledge and practice; case study from coastal British Columbia. Botany, 86(2), 103-115.

Turner, N. J., Ignace, M. B., \&lgnace, R. (2000).Traditional ecological knowledge and wisdom of aboriginal peoples in British Columbia. Ecological applications, 10(5), 1275-1287.

Tynsong, H.; Dkhar, M. and Tiwari B.K. (2020). Review: Traditional ecological knowledge of tribal communities of North East India. BIODIVERSITAS 21 (7): 3209-3224,

WCED, S. W. S. (1987). World commission on environment and development. Our common future, 17(1), 1-91. https://idl-bncidrc.dspacedirect.org/bitstream/handle/10625/152/WCED_v17_doc149.pdf.

Zeng, X. T., Huang, G. H., Chen, H. L., Li, Y. P., Kong, X. M., \& Fan, Y. R. (2016). A simulation-based water-environment management model for regional sustainability in compound wetland ecosystem under multiple uncertainties. Ecological modelling, 334, 60-77.

\section{Figures}




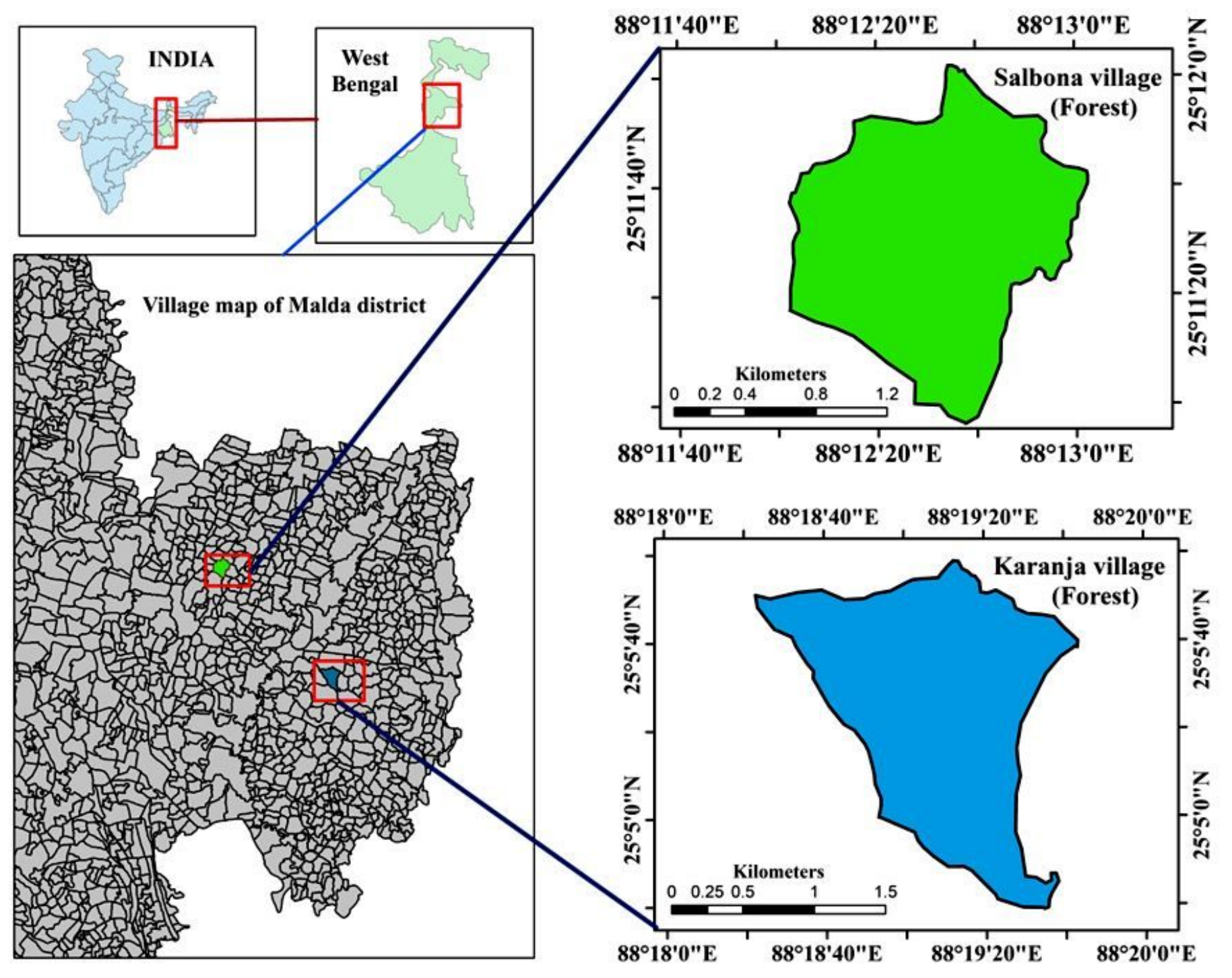

Figure 1

Location map of the study landscape. Note: The designations employed and the presentation of the material on this map do not imply the expression of any opinion whatsoever on the part of Research Square concerning the legal status of any country, territory, city or area or of its authorities, or concerning the delimitation of its frontiers or boundaries. This map has been provided by the authors. 


\section{Socio-ecological nexus between Traditional Ecological Knowledge (TEK) and \\ Ecosystem Services (ESs)}
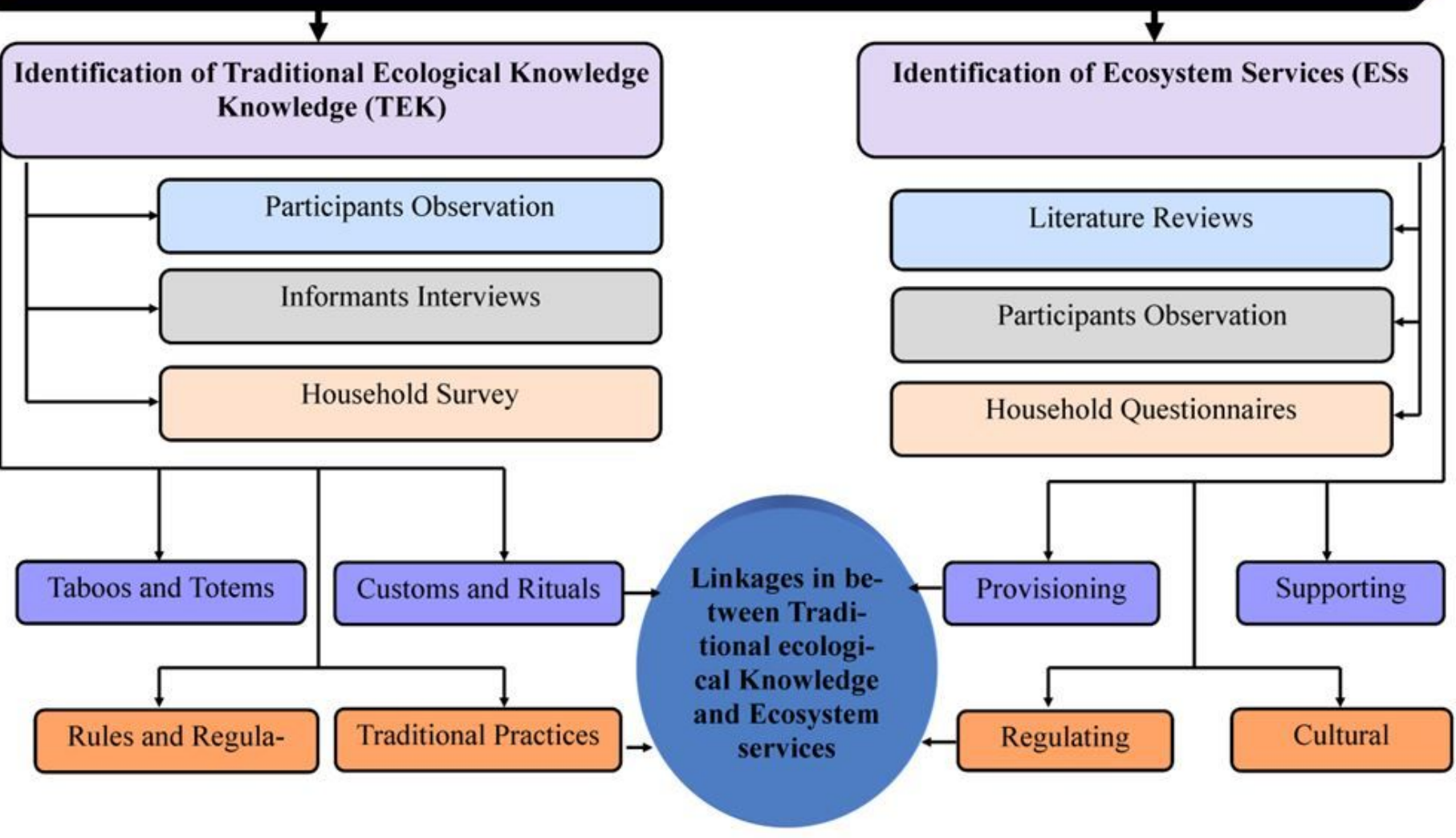

Figure 2

Methodological framework for evaluation the nexus between ESs and IEK 

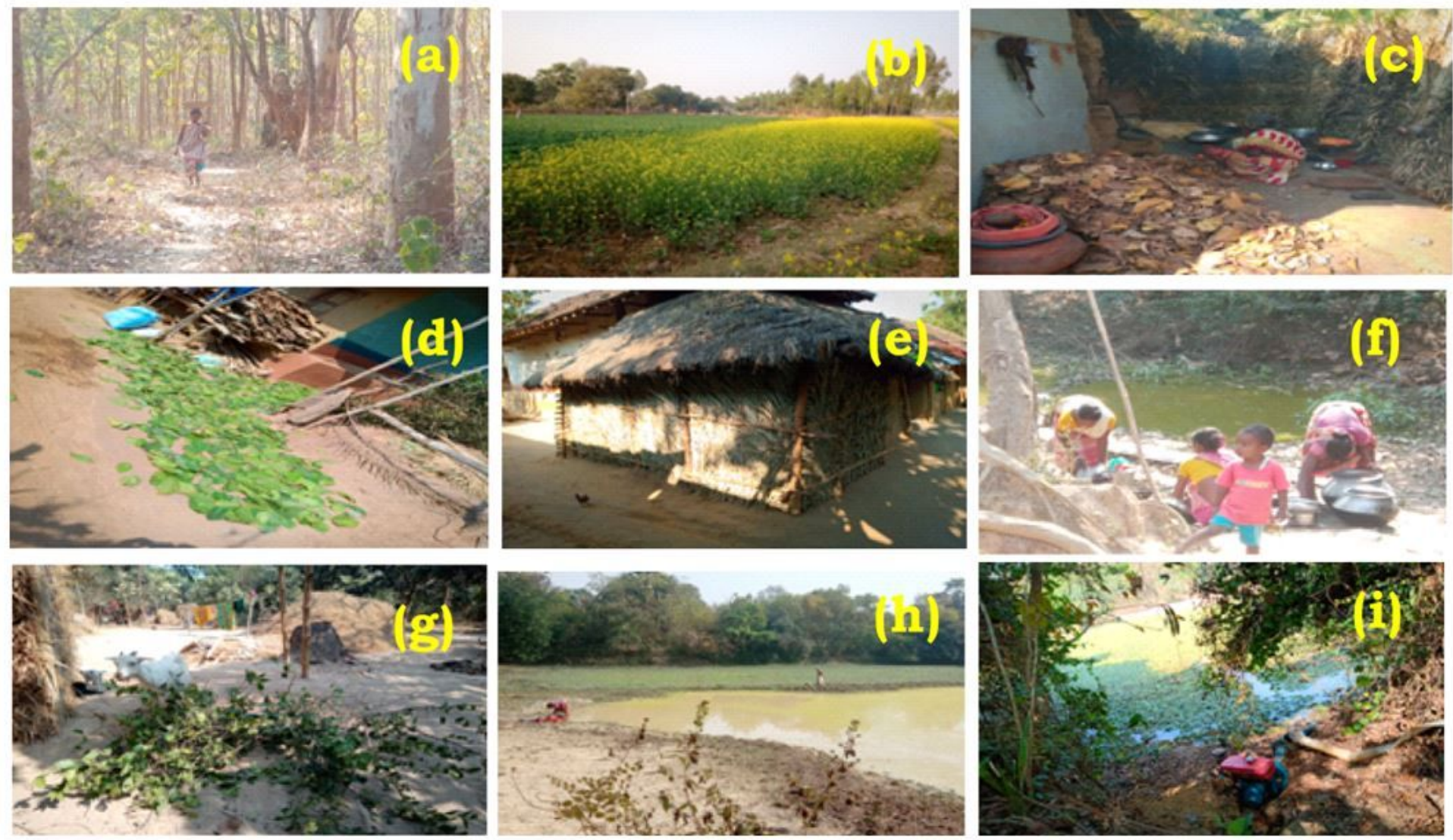

\section{Figure 3}

Glimpses of the study area (a) woman collecting fuel from the forest (b) agricultural land (c) woman cooking with forest leafs (d) Sal leaf plates for income earning (e) local material for housing (f) local ponds for washing utensils and clothes (g) wild edible plants (h) pond for bathing (i) irrigation from ponds. 


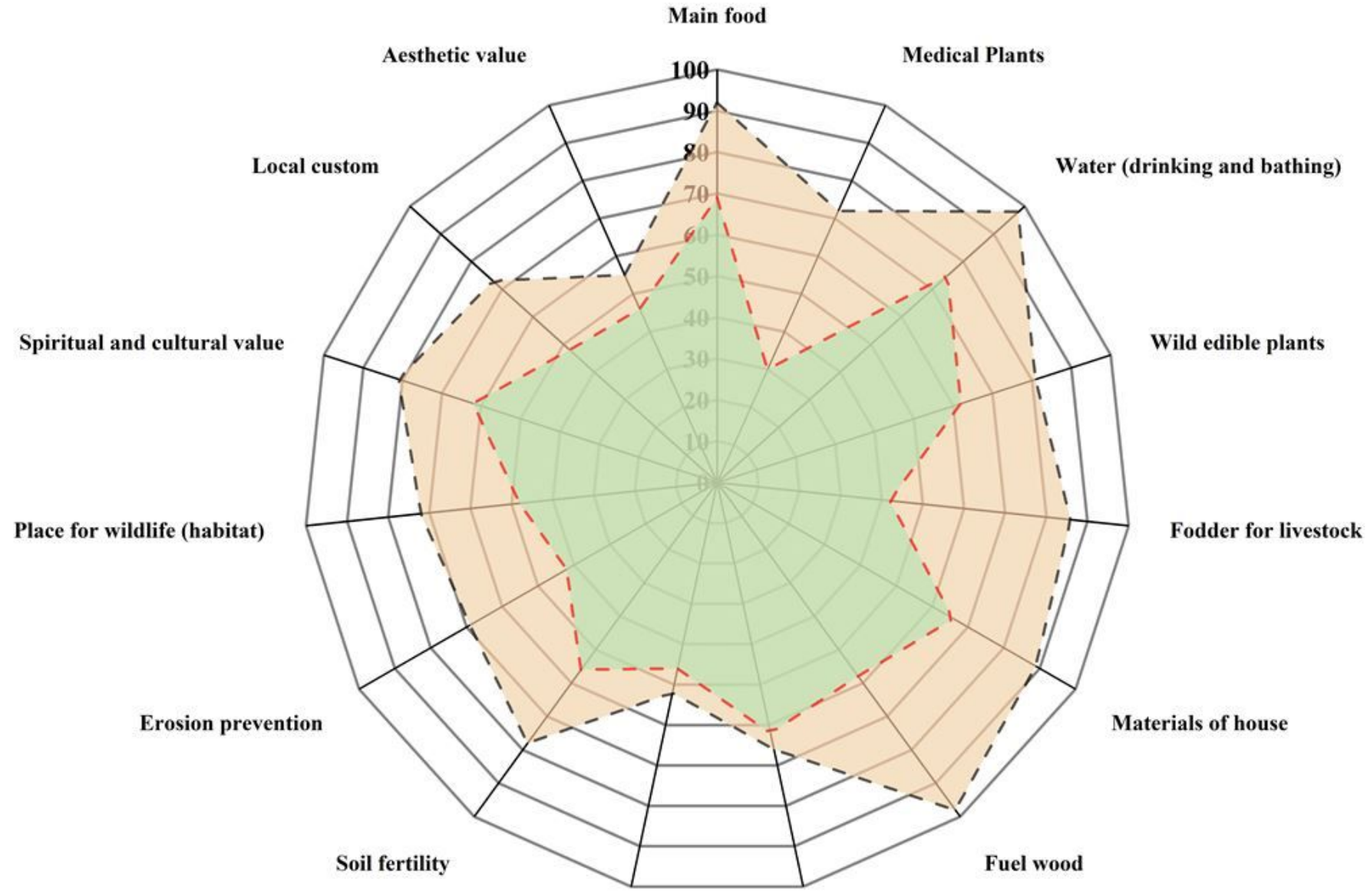

Air regulation Water regulation

$\square$ Perceived importance (\%) $\square$ Perceived vulnerability (\%)

\section{Figure 4}

Perceived importance and vulnerability of ESs in the study areas 


\section{Nexus between Ecosystem Services (ESs) and Human Well-Being (HWB)}

\section{$\square$}

Ecosystem Services (ESs)

$\square$

\section{Provisioning}

Main food

Water (drinking and bathing)

Fuel wood

Materials for house.

\section{Regulating}

Air purification

Water regulation and purification

Soil fertility

\section{Supporting}

Habitat for species

Erosion prevention

\section{Cultural}

Spiritual and cultural value

Local customs

Aesthetic value

\section{进}

\section{Human Well-Beings (HWB)}

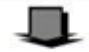

Basic materials for life

Access to food

Access to housing

Access to housing materials

Health

Medicinal plant

Felling well

Access to food

Security

Safe place

Natural hazards

Social relation

Respect among neighbour

Reliable relationship

Working with collaboration

Freedom

Participating in political work

Contribution to local action
Tribal Human

Well-Being and Ecosystem

Management

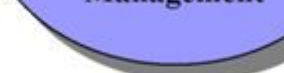

Magnitude of linkages between ESs and HWB

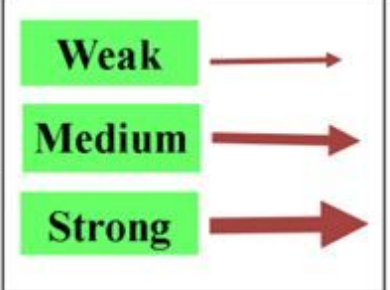

Figure 5

Conceptual framework regarding relationship between Ecosystem Services (ESs) and Tribal Human Well-Being (HWB) 


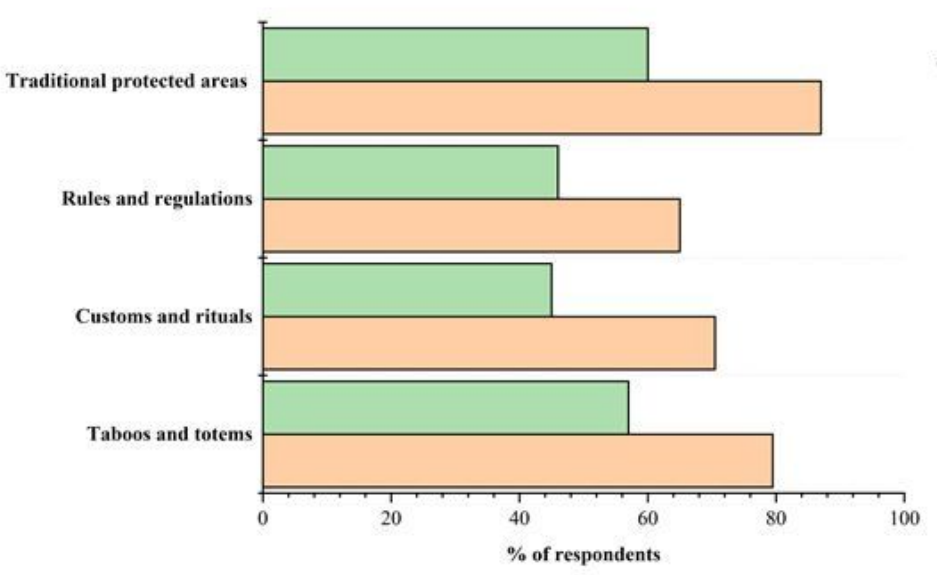

(a)

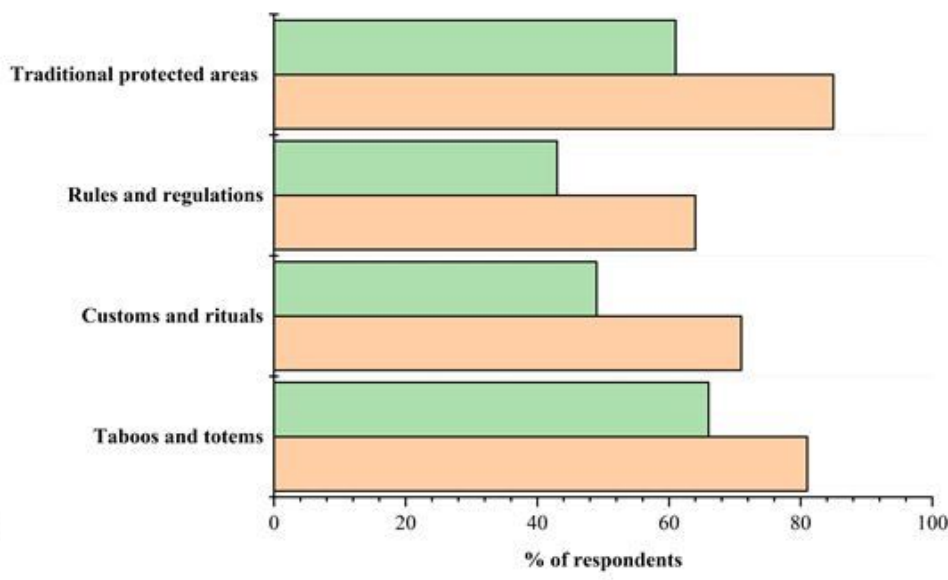

(b)

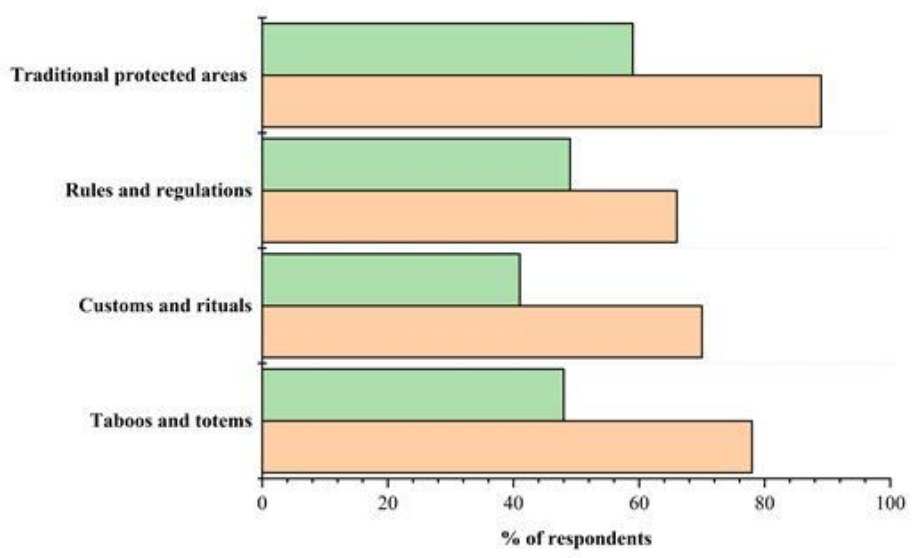

(c)

$\square$ Compliance $\square$ Awareness

Figure 6

Comparison between IEK awareness and compliance (a) Overall (b) Salbona and (c) Karanja 


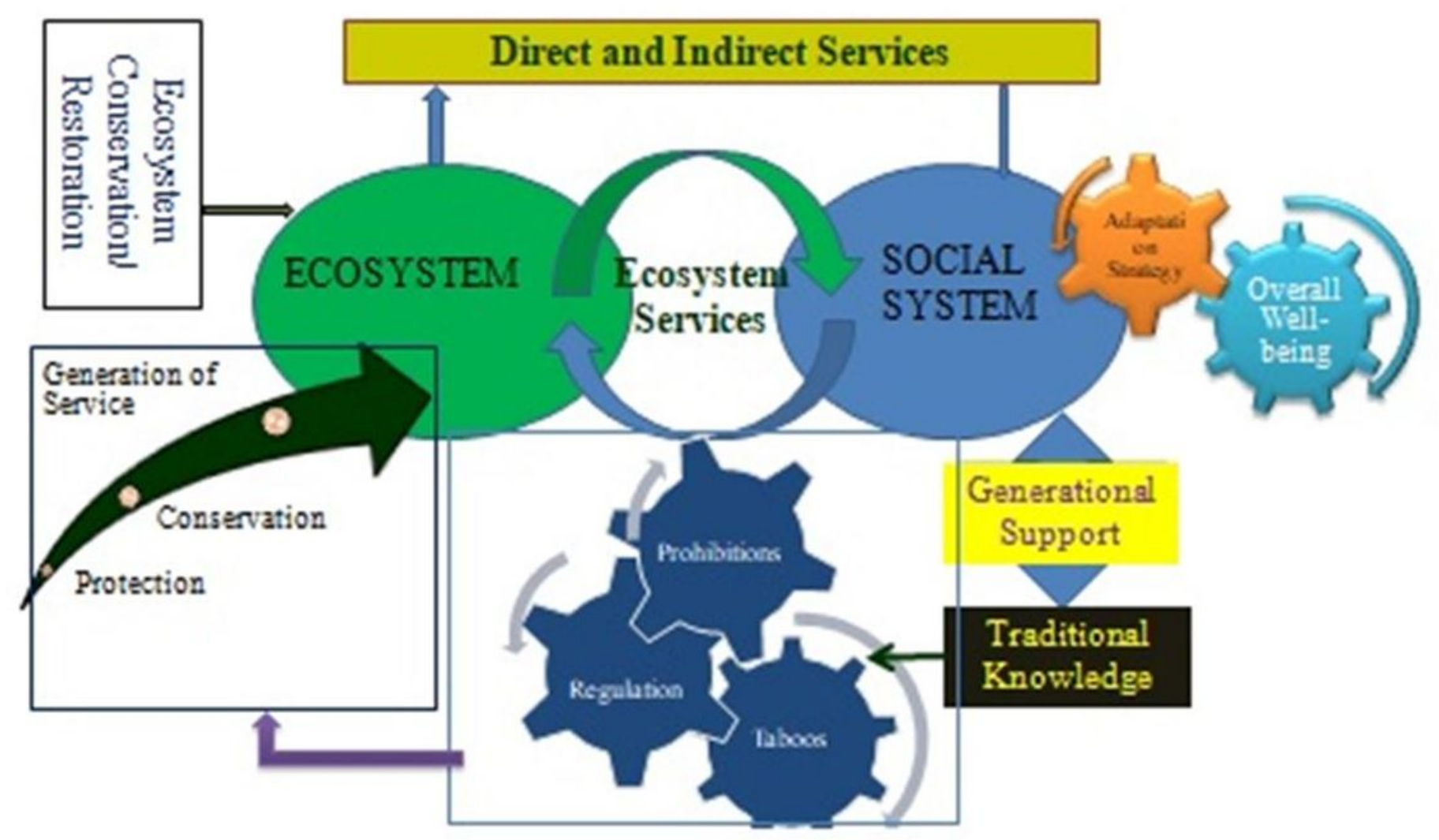

Figure 7

Socio-ecological system in tribal ecological landscapes 